\title{
IX. On the electromotive force of gases
}

\section{W. Beetz Ph.D.}

To cite this article: W. Beetz Ph.D. (1850) IX. On the electromotive force of gases, Philosophical Magazine Series 3, 36:241, 81-96, DOI: 10.1080/14786445008646432

To link to this article: http://dx.doi.org/10.1080/14786445008646432

曲 Published online: 30 Apr 2009.

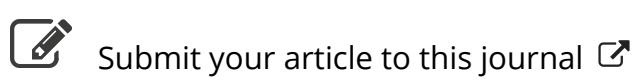

Џll Article views: 2

Q View related articles $₫$ 
THE

\title{
LONDON, EDINBURGH AND DUBLIN \\ PHILOSOPHICAL MAGAZINE
}

$\Lambda \mathbf{N D}$

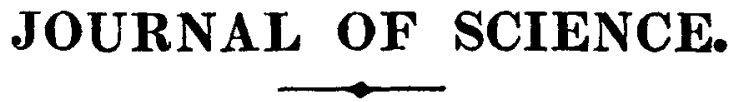

[THIRD SERIES.]

FEBRUARY 1850.

\author{
IX. On the Electromotive Force of Gases. \\ By W. BeEtz, Ph.D.*
}

TNVESTIGATIONS upon the measurement of the elec1 tromotive force of gas batteries are still wanting. The only experiments which aim at quantitative determination, are those in which Grove $\uparrow$ measured the change in the volumes of the gases contained in the tubes of the battery. As a rule, the diminution of the volumes was found greater in proportion to the activity of the current produced by the gas. If, however, we require to draw any conclusion regarding electrical excitation from this measurement, the hypothesis of Grove, viz. that the combination of the two gases used is the source of the electricity, and hence the circuit produces no effect when the gases have no chemical affinity for each other, must first be proved. Even then much deception might occur in consequence of secondary actions, such as were observed by Grove himself, so that in this manner we should never be able to obtain values which could in any way be regarded as measures of the electromotive force of gas batteries. Moreover, in consequence of the great inconstancy of gas batteries, at least with the use of most gases, experiments made with batteries which have remained closed for a long time consecutively, only give very dubious results, because with many of them the polarization entirely renders insensible the original electromotive force. Even in the case of those which are apparently the most constant, those where hydrogen and oxygen, and hydrogen and chlorine are used, the original force is quickly diminished; the polarization cannot however here attain any very considerable value, because the gases set free by

- Frum Poggendorf's Annalen, vol. lxxvii. p. 493.

+ Phil.Trans.1843, part. 2. p. 91. [See also Phil. Mag. vol. xxiv. p. 268.] Phil. Mag. S. 3. Vol, 36. No. 241. Feb. 1850. 
electrolysis are for the most part again removed, and thus after some time great constancy obtains.

The object of the following investigations is therefore to determine the electromotive force of the gas-battery quite independently of, or as much so as possible, the disturbing influence which prolonged closure of the current must exert. For this purpose, the method of compensation proposed by Poggendorff* naturally presented itself; in the application of which, the resistance of the circuit, the measurement of which is desired, is entirely unknown, and the circuit requires to be closed for a moment only. If three conductors, the resistances of which are $r, r^{\prime}$ and $r^{\prime \prime}$, meet in two points, $r$ being a circuit the electromotive force of which is $k^{\prime}$, and $r^{l}$ one the force of which is $k^{\prime \prime}$, the total intensity $\mathrm{J}^{\prime \prime}$ existing in $r^{\prime \prime}$ will be equal to the intensity which $k^{\prime \prime}$ would produce alone, minus that which $k^{t}$ would have produced by its own action; hence

$$
\mathrm{J}^{\prime \prime}=\frac{k^{\prime \prime}}{r^{\prime \prime}+\frac{r r^{\prime}}{r+r^{\prime}}}-\frac{k^{\prime}}{r^{\prime}+\frac{r r^{\prime \prime}}{r+r^{\prime \prime}}} \cdot \frac{r}{r+r^{\prime \prime}} .
$$

When $\mathbf{J}^{\prime \prime}=0$, we have

$$
\begin{gathered}
o=k^{\prime \prime}\left(r+r^{\prime}\right)-k^{\prime} r \\
k^{\prime \prime}=\frac{r}{r+r^{\prime}} \cdot k^{\prime} .
\end{gathered}
$$

Hence when the magnitude $k^{\prime}$ is given, $k^{\prime \prime}$ is also known by the measurement of $r$ and $r^{\prime}$. The resistances were measured by a rheochord spun over with German silver wire, in the same manner as that adopted by Poggendorff; $r$ is represented directly by a length of wire $b ; r^{\prime}$ consists of a length of wire $a$, the resistance of the circuit $k^{\prime}$ (a Grove's platina-zinc circuit), $=w$, and the resistance of a galvanometer, with a simple needle and but $\mathrm{few}$ coils, inserted in this closing wire, $=g$. Lastly, the resistance $r^{\prime \prime}$ consists of that of the circuit measured, and that of a delicate galvanometer $\mathbf{G}$ provided with an astatic arrangement, with its conducting wires. Let the resistances $w+g$ be $=R$. After the positive plate of the circuit under measurement $(e x . g r$. that platinum plate which is coated with hydrogen) had been connected by the wire $b$ with the platinum plate of the Grove's circuit, by the wire $a$ and the galvanometer $g$ with the zinc plate of the latter, a wire from the negative plate of the circuit under measurement (platinum coated with oxygen) was connected with a delicate galvanometer. Moreover, a wire from the platinum plate of

* Poggendorff's Annalen, vol. liv. p. 180. 
the Grove's circuit was placed in a cup of mercury, so that the current in $r^{\prime \prime}$ could be closed by rapidly immersing the second wire of the galvanometer in this cup. The length of $b$ was then fixed by the running clamp-screw of the instrument for measuring the resistance, and $a$ altered until the needle of the galvanometer $\mathrm{G}$ on closing the circuit $r^{\prime \prime}$ remained at 0 . We then have

$$
k^{\prime \prime}=\frac{b}{a+\mathrm{R}+b} k^{\prime}
$$

To find $\mathrm{R}, b$ then obtained another value $b^{\prime} ; a$ then became $a^{\prime}$, so that

$$
k^{\prime \prime}=\frac{b^{\prime}}{a^{\prime}+\mathbf{R}+b} k^{\prime}
$$

$R$ was calculated from both equations. In the present instance this method is very convenient, and sufficiently exact also, when the circuit to be measured is not too inconstant (as that in which hydrogen and oxygen are used). The following series of experiments show that this point was attended to. By a controlling measurement made by Ohm's method, I convinced myself of the applicability of the above process. Lastly, to ascertain the force $k^{\prime}$, the measuring platino-zinc circuit was closed by the wire of the rheochord in which $a$ had been previously measured, the needle of the galvanometer was then driven to $24^{\circ}$, which deflection $I$ had found to correspond to an evolution of 13.36 cubic centimetres on an average of the mixed gases in the proportion for forming water per minute. When the necessary resistance was $\rho$, we had

$$
k^{\prime}=\mathrm{R}+\rho
$$

where unity is that electromotive force, which, with a resistance of one centimetre German silver wire of 8.689 specific gravity (the average of four weighings), a centimetre of which weighs $0.00683 \mathrm{grm}$. (the mean of five determinations), evolves $13 \cdot 36$ cubic centimetres of the mixed gases per minute. With this value of unity, the force of the platino-zinc circuit is about $=42$. From these determinations the values found may be readily compared with any others. If, for example, we convert the measurements made by $M$. Poggendorff from his unit, in which the force of the Grove's circuit is about $=32$, into mine, this force becomes $42 \cdot 27$. A measurement may be adduced as an example of this.

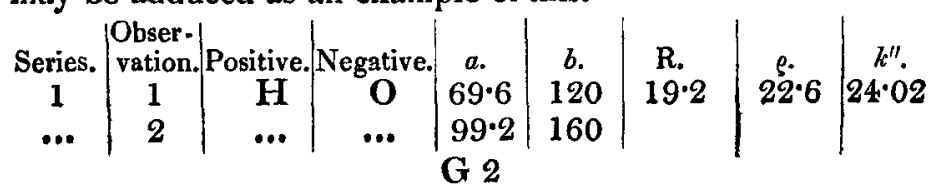


in which

$$
k^{\prime \prime}=\frac{b}{a+\overline{\mathbf{R}+b}}(\mathbf{R}+\rho) .
$$

The value found for $R$ in both observations was assumed to be constant during the whole series of observations, which never occupied a period of more than two hours; the same applies to $\rho$. All those connexions which were not (like $r^{\prime \prime}$ ) of equal value, or had been ascertained by calculation from their resistance (as those contained in $R$ ), were effected by short pieces of copper wire of the diameter of about a line.

Before detailing the experiments in full, a few words more must be said upon the preparation of the gas batteries. To obtain the platinized platinum in its most effective state, the plan proposed by M. Poggendorff was followed; the platinization was effected in a dilute solution of chloride of platinum by a current from two of Grove's cells, and thus a black coating was produced. It will be subsequently seen, however, that in the method of measuring adopted, a gray, imperfectly acting precipitate cannot produce any great changes in the force of the circuit, as the activity of the finely-divided layer is altogether only a secondary one. If two platinum plates are used to a gas battery, care must first be taken that they are not capable of exciting any voltaic tension of themselves; they must be tested as to their being perfectly homogeneous; and if they are not, they must be made so. Serious error may be fallen into in regard to this point, if the ordinary means are used for connecting the plates with each other in the conducting fluid for any time. If, for instance, upon one of the plates hydrogen in addition to the platinum is precipitated by a somewhat strong current, as is usually the case, and this is combined with a clean plate of platinum to form the circuit, hydrogen separates upon the latter plate; hence the current will cease before the oxygen evolved at the former plate has removed the hydrogen which it met with; consequently the plates appear to be homogeneous, but are far from consisting of pure platinum. I always took care that the hydrogen was first entirely dissipated, by causing all the plates about to be used in a series of experiments to act as the anodes for a short period. The oxygen and the chlorine by which they were then coated are much more easily removed, either by connecting all the plates, on the one hand, with another plate of platinum in a concentrated solution of platinum, so as to form a circuit, or by boiling them for a long time with water, or what is still better, by subjecting them to both these processes in succession. The plates, which were about four inches in length 
and a quarter of an inch in breadth, were therefore cemented into corks before platinization, and after the plates had been connected in the platinum solution, they were inserted into tubes about five inches in length; the tubes were then filled with water; this kept boiling for several minutes, and then replaced by the conducting fluid (dilute sulphuric acid of 1 per cent.). This was also heated to ebullition, and the open end of the tube then immersed in a vessel, which also contained some of the boiled conducting fluid. The gas under experiment, in its utmost state of purity, was then admitted into the tube in such a manner that about one-third of the plate dipped into the liquid. To connect two tubes so as to form a circuit, an inverted U-shaped tube, filled with the conducting liquid and connected at each end with a bladder, was dipped into the two vessels which contained the tubes; by this arrangement, diffusion of the gases through the liquid was better prevented than when both the tubes were placed in the same vessel. If, in measuring, the proportion of $a$ to $b$ in the first experiments was found to be too defective, so that the gas-circuit was traversed by a perceptible current, it was first again tried until the galvanometer $G$ remained at 0 ; the gas battery was then taken to pieces, and the whole process of filling it commenced anew. In the second measurement we commence with test experiments, which are not so far removed from the truth as to be capable of altering the battery perceptibly. The results last obtained only are given. After a little practice, we are generally enabled to avoid making too great mistakes in the position of the binding-screws, particularly when we have obtained an insight into the law which is deducible from the experiments.

\begin{tabular}{|c|c|c|c|c|c|c|c|c|}
\hline Series. & Observations. & Positive. & Negative. & $a$. & b. & R. & e. & $k^{\prime \prime}$ \\
\hline \multirow[t]{3}{*}{ I. } & 1 & H & 0 & $69 \cdot 6$ & 120 & $19 \cdot 2$ & $22 \cdot 6$ & $24 \cdot 02$ \\
\hline & $\begin{array}{l}\mathbf{z} \\
\mathbf{3}\end{array}$ & $\mathrm{H}$ & "ج̈ & 108.8 & $\begin{array}{l}100 \\
120\end{array}$ & & & $20 \cdot 23$ \\
\hline & 4 & $\mathrm{Pt}$ & 0 & 200 & 20 & & & 3.49 \\
\hline \multirow[t]{3}{*}{ II. } & 1 & $\mathbf{H}$ & o & 72 & 120 & $19 \cdot 2$ & 23 & $23 \cdot 98$ \\
\hline & $\begin{array}{l}2 \\
3\end{array}$ & $p_{t}$ & 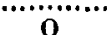 & $\begin{array}{l}102^{4} 4 \\
212\end{array}$ & $\begin{array}{r}100 \\
20\end{array}$ & & & 3.36 \\
\hline & 4 & H & $\mathbf{p}_{\mathbf{t}}$ & 108 & 120 & & & $20 \cdot 48$ \\
\hline \multirow[t]{5}{*}{ III. } & 1 & H & 0 & 71.2 & 120 & 16.8 & $25 \cdot 2$ & $24 \cdot 23$ \\
\hline & 3 & H & $\mathrm{CO}_{\mathrm{g}}$ & $\begin{array}{r}93 \cdot 6 \\
\end{array}$ & 120 & & & $21 \cdot 88$ \\
\hline & 4 & $\mathrm{CO}_{2}$ & $0^{2}$ & 350 & 20 & & & $2 \cdot 12$ \\
\hline & 5 & H & NO & $101 \cdot 2$ & 120 & .... & .......... & $21 \cdot 18$ \\
\hline & 6 & NO & 0 & 240 & $\begin{array}{r}20 \\
6\end{array}$ & $\ldots$ & $\cdots$ & 3.03 \\
\hline IV.* & i & H & $\mathrm{C}^{2}$ & 61.8 & 120 & $20 \cdot 4$ & $20 \cdot 2$ & $24-10$ \\
\hline
\end{tabular}

* The tubes filled as in series III. were retained. 
Table (continued).

\begin{tabular}{|c|c|c|c|c|c|c|c|c|}
\hline Series. & Observations. & Positive. & Negative. & a. & $b$. & R. & e. & $k^{\prime \prime}$ \\
\hline \multirow[t]{8}{*}{ IV. } & 2 & & & $89 \cdot 2$ & 160 & & & \\
\hline & 3 & H & No & $86 \cdot 4$ & 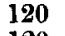 & ........ & 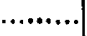 & $21 \cdot 48$ \\
\hline & 4 & H & CO & 208 & 120 & …........ & $\ldots \ldots \ldots \ldots$ & 13.98 \\
\hline & 5 & Co & $\mathrm{CO}_{2}$ & 132 & 40 & ......... & $\ldots, \ldots .$. & $8 \cdot 44$ \\
\hline & 6 & CO & 0 & 100 & 40 & .......... & ............ & 9.88 \\
\hline & 7 & H & $\mathrm{Cy}$ & $98 \cdot 6$ & 120 & ............ & .......... & $20 \cdot 38$ \\
\hline & 8 & Cy & & 208 & 20 & ........... & ............ & $3 \cdot 27$ \\
\hline & 9 & Co & No & 160 & 40 & & & $7 \cdot 37$ \\
\hline \multirow[t]{8}{*}{ V. } & I & $\mathrm{H}$ & CO & 116 & $\begin{array}{r}60 \\
190\end{array}$ & $26^{\circ} 0$ & $14 \cdot 8$ & $12 \cdot 40$ \\
\hline & $\begin{array}{l}2 \\
3\end{array}$ & $\mathrm{H}$ & 0 & $\begin{array}{l}58 \\
86\end{array}$ & $\begin{array}{l}120 \\
160\end{array}$ & & ...... & 24.08 \\
\hline & 4 & H & Cy & 93 & 120 & & & $21 \cdot 10$ \\
\hline & 5 & $\mathrm{CO}$ & $\mathrm{Cy}$ & 226 & 60 & $\cdots$ & ............ & $7 \cdot 84$ \\
\hline & 6 & Co & 0 & 134 & 60 & & & $11 \cdot 13$ \\
\hline & $7^{*}$ & H & $\mathrm{CH}_{2}$ & 150 & 120 & ............ & ............ & 16.54 \\
\hline & 8 & $\mathrm{CH}_{2}$ & & 186 & 40 & $\ldots \ldots \ldots$ & ........... & 6.48 \\
\hline & 9 & $\mathrm{CO}^{\circ}$ & $\mathrm{CH}_{2}$ & 292 & 30 & & & 3.52 \\
\hline \multirow[t]{6}{*}{ VI. } & 1 & H & Air & 101.0 & 120 & $17 \cdot 8$ & $\mathbf{2 2 \cdot 8}$ & $20 \cdot 50$ \\
\hline & 3 & H & "̈l & $\begin{array}{c}1400 \\
38\end{array}$ & 160 & & & $30 \cdot 25$ \\
\hline & 4 & Air & $\mathrm{Cl}$ & 180 & 60 & & & $9 \cdot 50$ \\
\hline & $\mathbf{5}$ & CO & $\mathrm{Cl}$ & 120 & 100 & $\mid \ldots \ldots \ldots$. & ........... & $17 \cdot 15$ \\
\hline & $6 \dagger$ & H & $\mathrm{NO}_{2}$ & 140 & 100 & ........... & .......... & $15 \cdot 83$ \\
\hline & 7 & $\mathrm{NO}_{2}$ & $\mathrm{Cl}$ & 138 & 80 & .............. & & $13 \cdot 84$ \\
\hline \multirow{15}{*}{ VII. } & 8 & H & co & 122 & 60 & 75,8 & 96.8 & $12 \cdot 25$ \\
\hline & $\begin{array}{l}1 \\
2\end{array}$ & $\mathbf{H}$ & 0 & $\begin{array}{r}85 \cdot 6 \\
119 \cdot 4\end{array}$ & $\begin{array}{l}120 \\
160\end{array}$ & 108 & $26 \cdot 6$ & $22 \cdot 99$ \\
\hline & 3 & $\mathbf{H}$ & $\mathrm{NO}_{2}$ & 116 & 120 & & & $20 \cdot 22$ \\
\hline & 4 & H & C & 197 & 100 & & & $13 \cdot 56$ \\
\hline & 5 & H & $\mathrm{Cl}$ & $35 \cdot 2$ & 160 & [........ & ........ & $32 \cdot 27$ \\
\hline & 6 & $\mathrm{NO}_{2}$ & 0 & 300 & 20 & $\mid \ldots \ldots \ldots$ & $\ldots \ldots$ & 2.52 \\
\hline & 7 & Cy & 0 & 360 & 8 & & $\cdots \cdots$ & 0.88 \\
\hline & 8 & $\mathrm{H}$ & $\mathrm{Cy}$ & $95 \cdot 6$ & 120 & & …...... & $\begin{array}{r}21.99 \\
1.5\end{array}$ \\
\hline & $\begin{array}{r}9 \\
10\end{array}$ & $\begin{array}{l}\mathrm{NO}_{2} \\
\mathrm{CO}^{2}\end{array}$ & Cy & 360 & 14 & |......... & $\cdots$ & 1.50 \\
\hline & 10 & CO & $\mathrm{N}$ & 12 & 40 & …….... & ㄱ........... & $6 \cdot 68$ \\
\hline & 12 & Co & Cy & $140 \cdot 6$ & 40 & ….......... & ........... & $8 \cdot 63$ \\
\hline & 13 & 0 & Ci & & 60 & & & $8 \cdot 60$ \\
\hline & 14 & $\mathrm{NO}_{2}$ & Cl & 13 & 60 & ;.......... & ........... & $11 \cdot 84$ \\
\hline & 15 & & $\mathrm{Cl}$ & 15 & 60 & & & $11 \cdot 26$ \\
\hline & 16 & $\mathrm{CO}$ & $\mathrm{Cl}$ & $92 \cdot 8$ & 100 & & & $20 \cdot 32$ \\
\hline \multirow[t]{5}{*}{ VIII. } & 1 & $\mathrm{H}$ & 0 & $69 \cdot 6$ & 120 & $19 \cdot 8$ & $21 \cdot 0$ & $23 \cdot 38$ \\
\hline & $2+$ & & & $99 \cdot 4$ & 160 & & & \\
\hline & $3+$ & $\mathbf{H}$ & Cu & 224 & 40 & & & $5 \cdot 15$ \\
\hline & 4 & $\mathrm{CO}$ & & & 120 & {$[\cdots . . . . . . .$.} & ……... & 16. \\
\hline & $\begin{array}{l}5 \\
6\end{array}$ & Co & $\mathrm{Cl}$ & 5 & 120 & ….......... & …...... & $\begin{array}{l}51.41 \\
25.39\end{array}$ \\
\hline \multirow[t]{2}{*}{ IX. } & 1 & $\mathrm{H}$ & 0 & 68 & 120 & $\mathbf{1 7 \cdot 2}$ & $24 \cdot 2$ & $24 \cdot 21$ \\
\hline & $3 \S$ & $\mathbf{H}$ & co & 230 & 40 & & & $5 \cdot 76$ \\
\hline
\end{tabular}

* 'The $\mathrm{CH}_{2}$ gave off an odour of æther.

+ The $\mathrm{NO}_{2}$ probably contained hydrogen.

* The CO probably contained hydrogen.

$\S$ The CO had been used previously; the other gases were freshly prepared. 
Table (continued).

\begin{tabular}{|c|c|c|c|c|c|c|c|c|}
\hline Series. & Observations. & Positive. & Negative. & $a$. & $b$. & R. & b. & $\boldsymbol{k}^{\prime \prime}$ \\
\hline \multirow[t]{14}{*}{ IX. } & 4 & $\mathrm{H}$ & $\mathrm{CH}_{2}$ & 112 & 120 & & & 19.94 \\
\hline & 5 & H & $\mathrm{Cl}$ & $29 \cdot 6$ & 160 & & ......... & 32.03 \\
\hline & 6 & & & 360 & 30 & & ........... & 3.05 \\
\hline & 7 & Co & 0 & 128 & 100 & & & 16.88 \\
\hline & 8 & co & $\mathrm{CH}_{2}$ & 112 & 60 & & .......... & $13 \cdot 13$ \\
\hline & 9 & $\mathrm{CH}_{2}$ & 0 & 344 & 30 & & & $3 \cdot 17$ \\
\hline & 10 & 0 & $\mathrm{Cl}$ & 244 & 60 & & ......... & $7 \cdot 72$ \\
\hline & 11 & $\mathrm{CO}$ & $\mathrm{Cl}$ & 54 & 120 & , $, \ldots, \ldots$ & …,...... & 25.98 \\
\hline & 12 & $\mathrm{CH}_{2}$ & $\mathrm{Cl}$ & 206 & 80 & & ............ & $10 \cdot 92$ \\
\hline & 13 & $\mathrm{HS}^{2}$ & 0 & 108 & 120 & ........... & .......... & $20 \cdot 26$ \\
\hline & 14 & HS & $\mathrm{CO}$ & 276 & 30 & & ........... & $3 \cdot 84$ \\
\hline & $\mathbf{3 5}$ & HS & $\mathrm{Cl}$ & 58 & 160 & & .......... & $28 \cdot 16$ \\
\hline & 16 & H & 0 & 69 & 120 & & …....., & 24.09 \\
\hline & 17 & H & $\mathrm{Pt}$ & 115 & 120 & & & 19.68 \\
\hline \multirow[t]{9}{*}{$\mathrm{X}$. } & 1 & H & 0 & 87.8 & 120 & $12 \cdot 4$ & $29 \cdot 8$ & $23 \cdot 00$ \\
\hline & 2 & & & $121 \cdot 2$ & 160 & & & \\
\hline & 3 & H & $\mathrm{Br}$ & 68 & 160 & & & 28.09 \\
\hline & 4 & 0 & $\mathrm{Br}$ & 270 & 40 & ........... & ........ & 523 \\
\hline & 5 & H & $\mathrm{CS}_{2}$ & 126 & 120 & ........... & ........ & $19 \cdot 60$ \\
\hline & 6 & $\mathrm{CS}_{2}$ & o & 240 & 20 & $\ldots \ldots \ldots$ & & $3 \cdot 10$ \\
\hline & 7 & H & $\mathrm{CO}_{2}$ & $112 \cdot 8$ & 120 & ....... & .......... & $20 \cdot 65$ \\
\hline & 8 & $\mathrm{CO}_{2}$ & 0 & 290 & 20 & & & $2 \cdot 62$ \\
\hline & 9 & $\mathrm{CO}_{2}^{-}$ & $\mathrm{Br}$ & 172 & 40 & ....... & & $7 \cdot 52$ \\
\hline & 10 & $\mathrm{CS}_{2}$ & $\mathrm{Br}$ & 152 & 40 & & & $8 \cdot 26$ \\
\hline \multirow{6}{*}{ XI. } & 1 & $\mathrm{H}$ & $\mathrm{CO}_{2}$ & $122 \cdot 2$ & 120 & $9 \cdot 8$ & 33 & $20 \cdot 38$ \\
\hline & 3 & $\ddot{\mathrm{H}}$ & $\dddot{c o ̈}$ & $142 \cdot 0$ & 60 & & & $12 \cdot 12$ \\
\hline & 4 & H & $\mathrm{Br}$ & 72.6 & 160 & ........ & …...... & $28 \cdot 32$ \\
\hline & $\mathbf{5}$ & $\mathrm{CO}$ & $\mathrm{Br}$ & 152 & 100 & ........ & .......... & $16 \cdot 37$ \\
\hline & 6 & $\mathrm{CO}_{2}$ & $\mathrm{Br}$ & 266 & 60 & & & $7 \cdot 65$ \\
\hline & 7 & $\mathrm{CO}^{-}$ & $\mathrm{CO}_{2}$ & 219 & 60 & & & $8 \cdot 88$ \\
\hline \multirow[t]{5}{*}{ XII. } & $\begin{array}{l}1 \\
8\end{array}$ & H & & $\begin{array}{l}73 \\
93 \cdot 8\end{array}$ & $\begin{array}{l}160 \\
200\end{array}$ & $10 \cdot 2$ & $31 \cdot 6$ & $27 \cdot 50$ \\
\hline & 3 & $\dddot{\mathrm{H}}$ & $\mathrm{CO}$ & 114 & 60 & & & $13 \cdot 61$ \\
\hline & 4 & H & $\mathbf{P}$ & 192 & 120 & & & 16.06 \\
\hline & 5 & CO & $\mathrm{Br}$ & 188 & 100 & & & 14.02 \\
\hline & 6 & $\mathbf{n}$ & $\mathrm{Br}$ & 200 & 80 & & & I 1.52 \\
\hline \multirow[t]{3}{*}{ XIII. } & 1 & $\mathbf{H}$ & 0 & $78 \cdot 2$ & 120 & 8.8 & $33 \cdot 6$ & $24 \cdot 58$ \\
\hline & $\dot{\mathbf{g}}$ & & & 115.2 & 100 & & & \\
\hline & 4 & $\mathrm{NO}_{2}$ & $0^{2}$ & 194 & 20 & & & 3.81 \\
\hline \multirow[t]{4}{*}{ XIVे. } & 1 & H & 0 & $79 \cdot 6$ & 120 & 6.8 & 36.0 & $24 \cdot 88$ \\
\hline & 8 & & & 108.4 & 160 & & & \\
\hline & 3 & H & $\mathrm{CH}_{2}$ & 149.4 & 120 & & & 18.59 \\
\hline & 4 & $\mathrm{CH}_{2}$ & 0 & $109 \cdot 4$ & 20 & & & $6 \cdot 28$ \\
\hline \multirow[t]{3}{*}{ XV. } & $\mathbf{1}$ & II & 0 & 78.4 & 120 & $9 \cdot 2$ & $32 \cdot 8$ & $24 \cdot 27$ \\
\hline & 3 & $\mathrm{H}$ & $\mathrm{CO}$ & $121^{\circ}$ & $\begin{array}{r}100 \\
60\end{array}$ & & & $13 \cdot 25$ \\
\hline & 4 & CO & 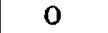 & $145 \cdot 4$ & 60 & & & 11.74 \\
\hline
\end{tabular}

It is distinctly evident from these series of experiments, that the electromotive forces of gases, connected by platinized platinum and dilute sulphuric acid so as to form gas batteries, follow the same law of Volta's tension series as the metals. 
Sufficient agreement of the experiments with this law might be obtained if the means of the experiments made with the same matters were taken, and these were considered as the true electromotive forces; but, properly speaking, only those experiments belonging to one and the same series ought to be compared with each other; because in them, even an alteration in the composition of a gas, an impurity acquired by it during the filling of the tubes, \&c. cannot exert any influence; those alterations only would become perceptible which the gas might have experienced in making the measurements themselves. In the following tables, the sums of the electromotive forces of different circuits are compared with the electromotive forces which were observed between the outermost members of these circuits.

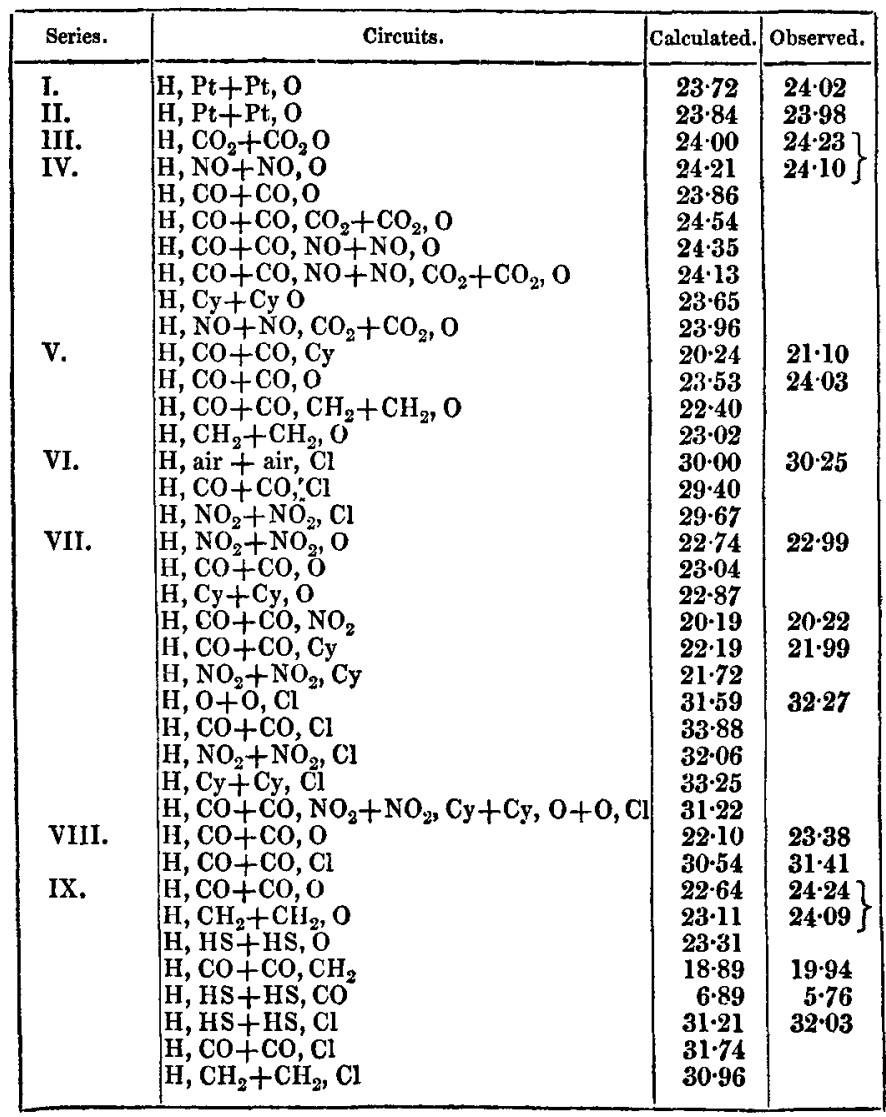


Dr. Beetz on the Electromotive Force of Gases.

Table (continued).

\begin{tabular}{|c|c|c|c|}
\hline Series. & Circuits. & Calculated. & Observed \\
\hline IX. & $\mathrm{H}, \mathrm{O}+\mathrm{O}, \mathrm{Cl}$ & $31 \cdot 93$ & \\
\hline $\mathrm{X}$. & $\mid \begin{array}{l}\mathrm{H}, \mathrm{HS}+\mathrm{HS}, \mathrm{CO}+\mathrm{CO}, \mathrm{CH}_{2}+\mathrm{CH}_{2}, \mathrm{O}+\mathrm{O}, \mathrm{Cl} \\
\mathrm{H}, \mathrm{CS}+\mathrm{CS}_{2}, \mathrm{O} \\
\mathrm{H}, \mathrm{CO}_{2}+\mathrm{CO}_{2} \mathrm{O}\end{array}$ & $\begin{array}{l}30 \cdot 91 \\
22 \cdot 70 \\
23 \cdot 27\end{array}$ & $23 \cdot 00$ \\
\hline & $\begin{array}{l}\mathrm{H}, \mathrm{O}+\mathrm{O}, \mathrm{Br} \\
\mathrm{H}, \mathrm{CS}_{2}+\mathrm{CS}_{2}, \mathrm{Br} \\
\mathrm{H}, \mathrm{CO}_{2}+\mathrm{CO}_{2}, \mathrm{Br} \\
\mathrm{H} \mathrm{CS}_{2}+\mathrm{CS}_{2} \mathrm{O}+\mathrm{Br}\end{array}$ & $\begin{array}{l}28 \cdot 23 \\
27 \cdot 86 \\
28 \cdot 17 \\
27 \cdot 93\end{array}$ & $28 \cdot 07$ \\
\hline XI. & $\begin{array}{l}\mathrm{H}, \mathrm{CO}+\mathrm{CO}, \mathrm{CO}_{2} \\
\mathrm{H}, \mathrm{CO}+\mathrm{CO}, \mathrm{Br}\end{array}$ & $\begin{array}{l}21 \cdot 00 \\
28 \cdot 49 \\
98 \cdot 03\end{array}$ & $\begin{array}{l}20 \cdot 38 \\
28 \cdot 32\end{array}$ \\
\hline XII. & $\begin{array}{l}\mathrm{H}, \mathrm{CO}+\mathrm{CO}, \mathrm{CO}_{2}+\mathrm{CO}_{2}, \mathrm{Br} \\
\mathrm{H}, \mathrm{CO}+\mathrm{CO}, \mathrm{Br} \\
\mathrm{H}, \mathrm{P}+\mathrm{P}, \mathrm{Br}\end{array}$ & $\begin{array}{l}28 \cdot 65 \\
27 \cdot 63 \\
27 \cdot 58\end{array}$ & $27 \cdot 50$ \\
\hline XIII. & $\mathrm{H}, \mathrm{NO}_{2}+\mathrm{NO}_{2} \mathrm{O}$ & $24 \cdot 66$ & 24.58 \\
\hline XIV. & $\mathrm{H}, \mathrm{CH}_{2}+\mathrm{CH}_{2}, \mathrm{O}$ & $24 \cdot 87$ & $24 \cdot 88$ \\
\hline XV, & $\mathrm{H}, \mathrm{CO}+\mathrm{CO}$, & $24 \cdot 99$ & $\mathbf{2 4} \cdot 27$ \\
\hline
\end{tabular}

The agreement between the observed and calculated values is sufficient to place beyond doubt the position, that gas batteries also follow the electromotor law of Volta's tension series.

The electromotive forces given in the following table are the mean results of the observations. The platinum coated with hydrogen is taken as the starting-point, the numbers opposite the several substances indicate the electromotive force which they excite when placed in one of the gas tubes, hydrogen being placed in the other. To give a clearer idea of the absolute value of the forces, those of platinum and zinc and platinum and copper have also been determined, referred to the same starting-point, and added to the series. In determining the meal, the observations VI., 6; VIII., 3 ; and IX., 3, have been neglected for the reasons there stated. For the sake of comparison, I have placed the series found by Grove* opposite my own.

$-31 \cdot 49$ Chlorine. 27.97 Bromine.

Chlorine.

Bromine.

Iodine.

Peroxides.

23.98 Oxygen.

21.33 Nitrous oxide.

Oxygen.

$21 \cdot 16$ Cyanogen.

20.97 Carbonic acid.

Nitric oxide.

20.52 Nitric oxide.

20.50 Air.

Carbonic acid.

Nitrogen.

* Philosophical Transactious, 1845, p. 359. 
20.13 Platinum.

$19 \cdot 60$ Sulphuret of carbon. C 18.36 Olefiant gas.

16.06 Phosphorus.

13.02 Carbonic oxide gas. Carbonic oxide gas.

3.82 Copper.

3.05 Sulphuretted hydrogen.

0 Hydrogen.

+19.68 Zine. pose water.

Camphor, volatile oils.

Olefiant gas.

Ether, alcohol, sulphur.

Phosphorus.

Metals which do not decom-

The above results settle the question of dispute between Grove* and Schœnbein $t$, as to whether, in an oxyhydrogen gas battery, the hydrogen alone, or both gases are active. The opinion of the latter author is that the hydrogen alone produces the current; the presence of the oxygen would only then be of use in lessening the charge of the free plate of platinum produced by the current. Grove's experiments show that the presence of air is necessary for the continuance of the current; for when the gas battery remained enclosed under a globe filled with air, from which the oxygen was removed by the combustion of phosphorus, the intensity of the current sunk to 0 , and on the admission of fresh air it gradually increased. This experiment, which corresponds perfectly with my experiments $\ddagger$ upon ordinary hydrogen batteries, Grove considers an argument against Schœenbein's view, and he is certainly correct. That the increase in the current caused by the oxygen is attributable to a diminution of the charge is indisputable; but it does not thence follow that the oxygen exerts no electromotive action. According to the experiments detailed above, the electromotive force of platinum and hydrogen is $=20.13$; of platinum and oxygen $=3.85$; the oxygen therefore contributes directly to the electric excitation, but certainly much less than the hydrogen. Air, nitrogen, and nitrogenous compounds act with oxygen still more feebly. The depolarizing action of the oxygen cannot be taken into consideration here, as the closure of the circuit is merely momentary.

As regards the situation of the electric excitation in the gas battery, this was found by Grove $\S$ to be at the point of contact of the platinum, gas and liquid. When the platinum did not

* Philosophical Transactions, 1843, p. 98. [Phil. Mag., vol, xxiv. p. 346.]

+ Phil. Mag., vol. xxii. p. 165.

$\$$ Poggendorff's Annalen, vol. Ixiv. p. 381.

\$ Philosophical Transactions, 1843, p.97. [Phil. Mag., vol. xxiv.p. 276.] 
touch the liquid, no current was set up, as we should expect; when it was entirely covered by the liquid, the current was very feeble. Five oxyhydrogen pairs were not capable of decomposing iodide of potassium; but when the angles of the platinum were in contact with the gas, this decomposition was effected by only one pair of plates. This law does not, however, appear to me generally established. In the case of gases which are copiously absorbed by water, as chlorine, it is certainly incorrect*; in fact, I found with the circuit of hydrogen and chlorine that the electromotive force was always greatest when the chlorine contained in the tube was perfectly absorbed (free from air). It certainly holds good in the case of other gases, but in a less degree, especially when in ascertaining the intensity of the current, the circuit is closed for longer than a moment. The small quantities of gas dissolved by the conducting liquid are very rapidly consumed by the gas evolved electrolytically, and the liquid may not be able to absorb gas throughout its entire mass with sufficient quickness to bring the current again to a moderate intensity. The experiments of Jacobi and Poggendorff + tend to show that platinum also exerts an action upon the gas when covered by the liquid; they found that in a voltameter with platinized electrodes, the quantity of gas evolved entirely disappears again, even after the water has risen above it. I however avoided the use of a voltameter, at the poles of which the gases were evolved, because the electromotive force produced by the polarization is always greater than that of an ordinary gas battery. The plates of platinum were cemented into the tubes in the ordinary way, after the upper parts of them had been thickly coated with shell-lac. Only that part of the plates thus isolated was surrounded by the gases; those parts with a metallic surface remained completely immersed in the conducting liquid. In a circuit arranged thus, I obtained an electromotive force of $15 \cdot 64$, which is much too small. The principal cause of this was, that the conducting liquid, which at that heat would have absorbed too little gas, on cooling not only absorbed hydrogen from above, but also air from below, from contact with which it was not protected.

If the platinization of the plates of platinum only increases the electromotive force of gas batteries because the counter

* Mr. Grove did not mean to assert that there was no action when the electrodes were immersed in the solution and the gas soluble, as he treats of this action in other parts of his paper; but that even under these circumstances the points of electric action were those at which the platinum, liquid and gas met.-Ev. Phil. Mag.

$\uparrow$ Poggendorff's Annalen, vol. lxx, p. 201. 
charge is diminished, we ought to find, on applying the compensating method, that a circuit with platinized plates exhibited no more power than one with polished plates, provided the platinum had been purified sufficiently. I therefore constructed gas batteries of polished plates of platinum, which had been boiled in concentrated nitric acid and then in water. These batteries yielded the following results:-

\begin{tabular}{|c|c|c|c|c|c|c|c|c|}
\hline Series. & Observations. & Positive. & Negative. & a. & $b$. & R. & e. & $k^{\prime \prime}$ \\
\hline \multirow[t]{6}{*}{ XVI. } & 1 & H & $\mathbf{0}$ & 72 & 120 & 14.4 & $27 \cdot 0$ & $24 \cdot 07$ \\
\hline & 2 & $\mathrm{H}$ & $C$ & $100 \cdot 8$ & 160 & & $\ldots$ & 25.94 \\
\hline & 4 & $\begin{array}{l}\mathbf{H} \\
\mathbf{H}\end{array}$ & $\begin{array}{l}\mathrm{Cl} \\
\mathrm{Br}\end{array}$ & $\begin{array}{l}20 \\
69\end{array}$ & $\begin{array}{l}100 \\
160\end{array}$ & …......... & ……....... & $\begin{array}{l}3.94 \\
27 \cdot 21\end{array}$ \\
\hline & 5 & 0 & $\mathrm{Br}$ & 258 & 20 & ............ & …… & 2.83 \\
\hline & 6 & 0 & $\mathrm{Cl}$ & 154 & 60 & ........... & ........... & $10 \cdot 87$ \\
\hline & 7 & $\mathrm{Br}$ & $\mathrm{Cl}$ & 184 & 40 & ........ & .......... & 6.94 \\
\hline
\end{tabular}

This agreement was to have been anticipated from the experiments which Faraday* made upon the condensing action of pure platinum upon gases; and Poggendorff + has already rendered it probable, that the primary forces of gas batteries with polished, gray, or black platinized plates, would be the same in each case. But at the same time the agreement of these observations yields a proof, that with the extremely short closure of the circuit, which the compensating method requires, the polarization does not attain any important value; otherwise the polished plates, which are capable of being more powerfully charged, would give smaller values.

I finally passed to experiments with gas batteries, the solid conductor of which consisted of some other body than platinum. I then met with a great difficulty in the small values of the electromotive forces, which in most cases rendered a determination of the relation existing between them almost impossible. Even on using Bunsen's coke batteries, from which Poggendorff $\ddagger$ anticipated great action, the forces were not very great, and moreover still variable. It was only with very great difficulty that I could cut discs of the coke, even from the same piece, which were tolerably uniform. This is of more consequence, because after what has been stated above, we have no means of rendering them uniform artificially. The pieces of coke were boiled for several hours with nitric acid, then with water, afterwards with dilute sulphuric acid, and again with water; yet I very frequently found that when the tubes were filled with any inodorous gas in which these pieces

* Experimental Researches, $\$ 570,605$.

+ Poggendorff's Annalen, vol. lxi. p. 598.

$\ddagger$ Loc. cit. 
of coke were placed, in a short time they gave off an odour of sulphuretted hydrogen. Those experiments in which this occurred always yielded very small results, and were of course rejected. In those detailed below, no sources of error were remarked. They show that the relation of the electromotive forces, when different gases are used, is exactly the same as with platinum. I have therefore divided the mean electromotive force of an oxyhydrogen platinum battery by that of an oxyhydrogen carbon battery, and divided the forces of the other platinum batteries by the quotient $c$. In this manner the last column denoted by " calculated" was obtained. The resistances were determined by separate experiments.

\begin{tabular}{|c|c|c|c|c|c|c|c|c|c|}
\hline \multirow{2}{*}{ Series. } & \multirow{2}{*}{ Observations } & \multirow{2}{*}{ Positive. } & \multirow{2}{*}{ Negative. } & \multirow{2}{*}{$a}$. & \multirow{2}{*}{$b$. } & \multirow{2}{*}{ R. } & \multirow{2}{*}{$\xi}$. & \multicolumn{2}{|c|}{$k^{\prime \prime}$. } \\
\hline & & & & & & & & Observed. & Calculated. \\
\hline XVII. & 1 & H & 0 & 208 & 60 & $12 \cdot 4$ & $|28 \cdot 6|$ & $11 \cdot 16$ & $11 \cdot 24$ \\
\hline XVIII. & $\mathbf{1}$ & $\mathbf{H}$ & 0 & 97 & 40 & 13 & $28 \cdot 2$ & $10 \cdot 99$ & $11 \cdot 24$ \\
\hline & 2 & $\mathbf{H}$ & $\mathrm{Cl}$ & 90 & 60 & .... & ...... & $15 \cdot 16$ & $14 \cdot 76$ \\
\hline & 3 & o & $\mathrm{Cl}$ & 160 & 20 & & ....... & $4 \cdot 27$ & 3.52 \\
\hline & 4 & Co & $\mathrm{Cl}$ & 192 & 60 & & ....... & $9 \cdot 33$ & $8 \cdot 65$ \\
\hline XIX. & 1 & $\mathbf{H}$ & o & 101 & 40 & 13 & $28 \cdot 2$ & $10 \cdot 70$ & $11 \cdot 24$ \\
\hline & 2 & HI & Cl & 80 & 60 & .... & $\ldots .$. & $16 \cdot 15$ & $14 \cdot 76$ \\
\hline & $\mathbf{3}$ & II & co & 220 & 40 & & $\mid \ldots . . .$. & 6.04 & $6 \cdot 10$ \\
\hline & 4 & co & 0 & 280 & 40 & .... & $\ldots \ldots$ & $4 \cdot 84$ & $5 \cdot 14$ \\
\hline & 5 & co & $\mathrm{Cl}$ & 160 & 60 & 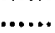 & & $10 \cdot 60$ & 8.65 \\
\hline $\mathrm{XX}$. & 1 & H & 0 & 94 & 40 & 14 & $\ddot{27 \cdot 2}$ & $11 \cdot 14$ & $11 \cdot 24$ \\
\hline & 2 & H & $\mathrm{CO}$ & 160 & 40 & & & $6 \cdot 75$ & $6 \cdot 10$ \\
\hline & 3 & co & o & 200 & 20 & $\ldots$ & $\ldots \ldots$ & $4 \cdot 45$ & $5 \cdot 14$ \\
\hline & 4 & $\mathrm{CO}$ & $\mathrm{Cl}$ & 180 & 40 & & ...... & $7 \cdot 07$ & $8 \cdot 65$ \\
\hline & $\overline{\mathbf{5}}$ & 0 & Cl & 220 & 20 & ..... & $\ldots . .$. & $\mathbf{3} \cdot 24$ & $3 \cdot 52$ \\
\hline & 6 & H & Cl & 98 & 60 & . & $\ldots \ldots$. & $14 \cdot 37$ & $14 \cdot 76$ \\
\hline & 7 & $\mathrm{H}$ & $\mathrm{Br}$ & 122 & 60 & ..... & $\mid \ldots . . .$. & $12 \cdot 61$ & $13 \cdot 11$ \\
\hline & 8 & o & $\mathrm{Br}$ & 350 & 20 & ... & ........ & $2 \cdot 90$ & 1.87 \\
\hline & 9 & $\mathrm{Br}$ & $\mathrm{Cl}$ & 300 & 10 & $\cdots$ & $\ldots . .$. & $1 \cdot 27$ & 1.65 \\
\hline XXI. & 1 & H & 0 & 127 & 60 & $12 \cdot 4$ & $28 \cdot 4$ & $12 \cdot 28$ & $11 \cdot 24$ \\
\hline
\end{tabular}

$c=0 \cdot 1.687$.

The factor $c$ evidently depends upon the condensation which the gases experience at the surface of the solid conductor, and by which the coating of the metal with the gases is rendered more perfect. Hence this method might be used for determining the relative condensing force of different bodies, if the absolute magnitudes of the electromotive forces in most matters were not too small. The coefficient 0.4687 cannot certainly be considered as applying to carbon generally. Other kinds of carbon may differ very greatly.

I obtained the following values in the case of gas batteries with chemically pure plates of silver, which were silvered galvanically :- 
Dr. Beetz on the Electromotive Force of Gases.

\begin{tabular}{|c|c|c|c|c|c|c|c|c|c|}
\hline \multirow{2}{*}{ Series. } & \multirow{2}{*}{ Observations. } & \multirow{2}{*}{ Positive. } & \multirow{2}{*}{ Negative. } & \multirow[b]{2}{*}{ a. } & \multirow[b]{2}{*}{$b$. } & \multirow{2}{*}{ R. } & \multirow[b]{2}{*}{ e. } & \multicolumn{2}{|c|}{$k^{\prime \prime}$} \\
\hline & & & & & & & & Observed. & Calculated. \\
\hline XXI. & 1 & H & o & 360 & 10 & $14 \cdot 4$ & 27.0 & 1.07 & 1.08 \\
\hline XXII. & i & H & 0 & 366 & 10 & $9 \cdot 2$ & $32 \cdot 8$ & $1 \cdot 09$ & $1 \cdot 08$ \\
\hline & 2 & $\mathbf{H}$ & $\mathrm{CO}$ & 350 & $4 \cdot 6$ & & ....... & $0 \cdot 54$ & 0.58 \\
\hline & 3 . & co & 0 & 360 & A & & ...... & $0 \cdot 49$ & $0 \cdot 50$ \\
\hline
\end{tabular}

$c=0.0449$.

Although the preceding experiments afford many explanations of the action of gas batteries, yet they cannot possibly decide upon the source of the force in them. The solution of this question, however, in my opinion, would constitute nothing less than a final decision as to the nature of electricity of contact. In fact, the phænomena which have just been discussed rank perfectly with those which occur in the excitation of a current by solid conductors, with the only difference, that the state of aggregation in the case of the gases may be altered by the solid bodies in contact with them, which is not the case with solid conductors: hence the difference in the absolute values in the case of the forces of the gas batteries, whilst their relative values remain the same. The special activity of the positive gases (as hydrogen) depends solely upon the electromotive force of platinum and hydrogen being far greater than that of platinum and oxygen, or even platinum and chlorine; the phænomenon observed by Matteucci* and others, that small quantities of hydrogen may exceed the action of large quantities of oxygen, then forms a simple analogy with the action of amalgams, in which the positive metal (potassium, zinc) preponderates.

Lastly, regarding the arrangement of the metals and gases in an electromotor series, as given above, we must not deceive ourselves regarding its importance. The metals mentioned (platinum, copper and zinc) hold that position to those gas batteries which contain plates of platinum; in the case of other batteries, their position would be different. Whilst, for instance, zinc is then positive towards hydrogen with a force of $19 \cdot 68$, Buff + found a zinc plate coated with platinum positive towards a polished plate, and subsequently gave a numerical value to this tension $\ddagger$; from this he deduced the conclusion, that the position of hydrogen was nearer the positive end of a tension series than zinc, a conclusion which is evidently

* Comptes Rendus, xvi. p. 846. 222.

† Annal. der Chem. und Pharm., val, xli. p. 136; Archiv. de l'Electr. ii.

$\ddagger$ Poggendorff’s Annalen, vol. lxxiii, p. 505. 
premature. He would only have been correct, provided, in the gas batteries, the metallic plates were so completely coated with the gases that they only acted as conductors, and did not come into immediate contact with the liquid. This is, however, evidently not the case; on the other hand, we always observe the simultaneous action of the metal forming the basis of the battery; a phænomenon which is evident when the gas does not come into contact with the plate itself, but is only slightly dissolved by the liquid; whilst, when the gas comes into immediate contact, $i$. e. at the point of contact of the metal, the gas and the liquid, the action of the gas is at its maximum, and the values then obtained are those given above. I cannot therefore entirely agree with one statement made by M. Buff*, viz. "that the same effect is produced by the layer of hydrogen at the negative plate of platinum (on polarization), as also by the layer of oxygen at the positive plate of platinum, as when, instead of two strips of platinum, a strip of solid hydrogen and a strip of solid oxygen had been introduced into the acid;" but I entirely agree with the following remark on this point:- "The electromotive action excited by the immediate contact of hydrogen and oxygen, or the electric difference of the two matters, denotes the extreme limit of the resistance (of the counter force) which can possibly be produced by the polarization of two metals in decomposing cells. This limit is more approximated in proportion to the power possessed by the immersed plates to become coated with the gases, and to the completeness with which the direct contact of the metallic with the liquid conductor is by this means avoided. If the partly immersed strips could be completely isolated from the liquid by the gases with which they become coated, the chemical nature of the metallic masses would be a matter of perfect indifference." But since the metals are not all equivalent when the polarization is at its maximum, it can never be admitted that the plates are completely coated with the gas, nor can the polarizing values be regarded as the true electromative forces of the gases concerned.

Here, I think, is to be sought for the cause of the phrnomenon, that plates of the same metal yield a far greater electromotive force when they are coated with the gases by polarization than when this is produced by any other means; they are coated much more perfectly by polarization. The electromotive force thus produced in M. Poggendorff's + experiments, when reduced to my unit, would be 55 for polished

* Loc. cit + Poggendorff"s Annalen, vol. lxx. p. 179-189. 
platinum, 40 for platinized platinum, whilst I found it $=24$ with the gas battery.

I should wish on this point to recall the attention of the reader to the remarks of this philosopher* upon the predominating action of secondary batteries over that of the gas hattery.

X. The Astronomer Royal on a Problem of Geodesy.

To the Editors of the Philosophical Magazine and Journal. Gentlemen,

A KNOWLEDGE of the result of the following investi-
gation is so necessary for the correct calculation of the large triangles of modern surveys, and the investigation itself is so easy, that I imagine that an equivalent solution must have appeared already. I have not however seen one, and I therefore think it possible that the publication of my investigation may not be entirely without utility.

The problem which I propose to myself is "To find the curvature-excess upon a surface differently curved in different directions;" the term curvature-excess having the same meaning for this surface which spherical-excess has for a spherical surface; namely, the quantity by which the sum of the three angles of a triangle (as observed with a theodolite whose axis at each angle of the triangle is made perpendicular to the surface) exceeds $180^{\circ}$. And before entering upon the investigation, 1 wish to point out that the "geodetic lines" and "geodetic triangles" of speculative geometers have nothing to do with this problem. The triangles with which we are concerned here are the rectilinear triangles formed by the rays of light, proceeding in straight lines (except so far as they are influenced by refraction, which does not sensibly affect their azimuths) from one station to another. The best geometers possessing a practical acquaintance with surveys,Dalby, Delambre, and Everest, - have fully understood the difference.

I must also point out, that, unless we proceed to an excessive degree of complication, it is impossible to give the solution with the same degree of completeness as for a spherical triangle; because a surface is not defined by a mere knowledge of the principal radii of curvature for one point of the surface, for a higher order of superficial distances from that point than the second. Thus, to take a very simple case, a surface having given principal radii of curvature may be either at the equa-

* Loc. cit. vol, lxi. p. 600. 